\title{
Bilješka o urednicima
}

Ivana Cvijović Javorina (Zagreb, 1985.) studentica je Poslijediplomskoga doktorskog studija moderne i suvremene hrvatske povijesti u europskom i svjetskom kontekstu Odsjeka za povijest Filozofskog fakulteta u Zagrebu. Na istom je fakultetu stekla zanimanje profesora povijesti i njemačkog jezika i književnosti. Zaposlena je u III. gimnaziji u Zagrebu kao nastavnik njemačkog jezika. Zajedno s Dragom Roksandićem dosad je uredila pet zbornika radova Desničini susreti te publikaciju Vladan Desnica i Desničini susreti: pogled unatrag, pogled unaprijed, objavljenu povodom 25. obljetnice osnutka Desničinih susreta. Njezina su područja interesa oralna historija, generacijska povijest, povijest mladeži, kultura sjećanja te procesi suočavanja s prošlošću.

Drago Roksandić (Petrinja, 1948.) redovni je profesor u trajnom zvanju na Odsjeku za povijest Filozofskog fakulteta Sveučilišta u Zagrebu. Predstojnik je Katedre za povijest Srednje i Jugoistočne Europe, voditelj modula Diplomskog studija ranoga novog vijeka te nositelj kolegija „Teorije i metode” na Poslijediplomskom doktorskom studiju moderne i suvremene hrvatske povijesti. Voditelj je projekta Triplex Confinium (utemeljenog 1996. godine) i znanstvenog programa Desničini susreti. Jedan je od utemeljitelja fakultetskog Centra za komparativnohistorijske i interkulturne studije. Autor je brojnih knjiga i znanstvenih radova, a posljednje djelo mu je $U$ Ninu i Danasu iz 2011. godine. (Vidjeti biobibliografiju do 2008. godine u: Hrvoje Petrić, „Živjeti Triplex Confinium (u povodu 60. godišnjice rođenja prof. dr. sc. Drage Roksandića)", Ekonomska i ekohistorija, vol. 4, br. 4, str. 151.-231.) 